\title{
Correction to: Cultural dimensions in online purchase behavior: evidence from a cross-cultural study
}

\author{
Francesca Pratesi ${ }^{1}$ - Lala $\mathrm{Hu}^{2}$ (D) Riccardo Rialti ${ }^{3}$ - Lamberto Zollo ${ }^{3}$. \\ Monica Faraoni ${ }^{3}$
}

Published online: 5 July 2021

(c) The Author(s) 2021

\section{Correction to: Italian Journal of Marketing https://doi.org/10.1007/s43039-021-00022-z}

The original version of this article contained a mistake. Francesca Pratesi was not listed among the authors and the sequence of the author names was incorrect. The corrected authorship is as follows:

Francesca Pratesi ${ }^{1}$, Lala $\mathrm{Hu}^{2}$, Riccardo Rialti ${ }^{3}$, Lamberto Zollo ${ }^{3}$, Monica Faraoni ${ }^{3}$.

The original article has been corrected.

Open Access This article is licensed under a Creative Commons Attribution 4.0 International License, which permits use, sharing, adaptation, distribution and reproduction in any medium or format, as long as you give appropriate credit to the original author(s) and the source, provide a link to the Creative Commons licence, and indicate if changes were made. The images or other third party material in this article are included in the article's Creative Commons licence, unless indicated otherwise in a credit line to the material. If material is not included in the article's Creative Commons licence and your intended use is not permitted by statutory regulation or exceeds the permitted use, you will need to obtain permission directly from the copyright holder. To view a copy of this licence, visit http://creativecommons.org/licen ses/by/4.0/.

Publisher's Note Springer Nature remains neutral with regard to jurisdictional claims in published maps and institutional affiliations.

The original article can be found online at https://doi.org/10.1007/s43039-021-00022-z.

Lala $\mathrm{Hu}$

lala.hu@unicatt.it

1 Project and Finance Consulting, Resolvo S.R.L., Florence, Italy

2 Department of Economic and Business Management Sciences, Catholic University of the Sacred Heart, Milan, Italy

3 Department of Economics and Management, University of Florence, Florence, Italy 